\title{
Scientific Identification of Definitions of the Labor Market and Labor Force in the Context of the Post-Industrial Management Paradigm
}

\author{
Viktoria V. Grigoryeva1 \\ Elena I. Makrinova² \\ Elena P. Borshevskaya ${ }^{1}$ \\ Ekaterina S. Pereverzeva ${ }^{3}$ \\ Olga M. Pasynkova ${ }^{1}$
}

\begin{abstract}
1 Voronezh State University of Engineering Technologies, Russian Federation 2 Belgorod University of Cooperation, Economics and Law, Russian Federation

${ }^{3}$ Federal state educational institution of higher professional education "Belgorod Law Institute of the Ministry of Internal Affairs of the Russian Federation", Russian Federation; Correspondence: Viktoria V. Grigoryeva, Voronezh State University of Engineering Technologies, Russian Federation.E-mail: vickierus@mail.ru; makrinova@bukep.ru; ebogah0578@yandex.ru katkatrin200@gmail.com; pasol-30@mail.ru
\end{abstract}

Doi:10.5901/mjss.2015.v6n6s2p334

\section{Abstract}

The authors of the article systematize basic definitions of management in view of the principles of system approach to identification of concepts, terminological continuity, and internal consistency. The theory of value and labor relations from antique to modern theories was studied; the authors' interpretation of the labor market, labor, and the price of labor was given.

Keywords: labor, labor theory, manpower, labor potential, shots, personnel, human resources, price of labor, wages, labor contribution

\section{Introduction}

Changes in public conscience and increase of the role of human in modern system of production require the necessity for reconsideration and rethinking of existing categories, their unification and adaptation to international standards of theory and practice of social and labor relations. This will allow providing the unity of approaches to determining the main aspects of this problem and having a basis for further research of the issues of labor management and development of its new forms and methods.

The existing gap between formation of new phenomena in social \& labor sphere and their scientific understanding, certain inertness of teaching systems and managerial thinking determined wide differentiation of terms, some of which, as a matter of fact, lost their initial sense or require specification in new terminological context. Thus, systematization of conceptual construct of labor categories is an actual, but at the same time complex and multi-aspect problem which is important in scientific and practical aspect and which should be solved on the basis of terminological succession, internal consistency as to separate system of notions, and adequate identification of new phenomena in the practice of management.

The task of the research consists in scientific analysis of the key notions of the studied sphere of knowledge for the purpose of identification of used definitions in the context of post-industrial managerial paradigm on the basis of the method of historical discourse of the most valuable works of the classics of economic theory and view of modern scientists on the problems of development of labor and labor force market.

\section{Review of Scientific Opinions}

Emergence and development of the science of labor relations was caused by appearance of various theories. Attention of great thinkers, scientists-economists, and practitioners was at all times drawn to issues of labor which determined the rates of society development. They were interested in the role of labor in formation of product price, price of labor and its 
value, and connection between labor and newly created products. In ancient times, the works of the philosopher Aristotle viewed the problem of congruence of goods and put a question: what determines the ratio of exchange? At those times, there was no unambiguous answer to that question in this works, but Aristotle gave several suggestions as to that. Thus, his works state that "everything should be measured by something common, and payback will take place when there is equation so that shoemaker's products correlates with farmer's products, like farmer treats shoemaker" (Zhebelev S.A., 1933).

W. Petty formulated a provision stating that product price is based on the quantity of labor spent for its manufacture. He also expressed the thought that "labor is the father and active principle of wealth, as lands are the mother" (Petty W. 1940).

A large contribution to development of science of labor was done by the English economic Adam Smith (Smith A., 1993). In A. Smith's understanding, the sources of all incomes, of which the price is comprises, have a labor origin. Thus, he writes, "Payment for labor is a natural reward for labor, or wages". Then, "... rent is the first deduction from labor product, applied to earth tilling... income is the second deduction, applied to earth tilling. Such deduction is performed with a product of another labor".

After A. Smith, there was a division of economic schools and formation of two completely different directions: labor theory of cost and theory of production factors. The followers of the first direction are David Ricardo and later - Karl Marx. The followers of the second direction include J.B. Say and later generations of researchers of non-Marxist direction.

D. Ricardo thought that only labor was the basis for any cost (Ricardo D., 1958). According to him, evaluation of labor of various qualities was set in the market very precisely and largely depends on comparative skill of the worker and tension of the performed work, i.e., quantity of necessary labor in a product is determined not by actual cost at the enterprise but by free competitive market. Rent and profit, according to Ricardo, is a part of unpaid labor of the workers. The value of wages was determined by the cost of means of living of worker and his family. If worker's labor was the only source of the cost or price, then, according to D. Ricardo, the growth of wages without the growth of labor efficiency does not influence the change of price, but leads to reduction of entrepreneur's profit and, vice versa, growth of capitalists' income reduces wages.

Labor theory of value was led to logical finish by Karl Marx in his fundamental work "Capital" (Marx K., 1995). A central part in the economic theory of $\mathrm{K}$. Marx is occupied by science of labor. The main role in this theory belongs to science of value added, as on its basis K. Marx determined a mechanism of formation of product cost. He introduced a provision of dual nature of labor, in which specific labor creates consumer cost, and abstract human labor creates product cost. Specific cost meant "spending human work force in a specific rational form" which creates consumer value.

According to K. Marx, abstract labor is similar human labor without any differences, as "spending human work force in physiological aspect" which "creates product cost". Indeed, one of the forms of labor manifestation is cost of physiological energy of workers. However, labor has other manifestations, like interrelations of workers with production means and with each other. Determination of labor manifestation forms has certain sense, for example, during study of such aspects of labor as level of its difficulty, tension, content, etc. However, labor as spending human force in physiological aspect, in isolation from other forms of its manifestation, is impossible. Understanding labor only as one of the forms of its manifestation means explaining it not in the full way.

Labor can create certain value of products (goods) only within the limits of its value. Participating in creation of goods, labor takes part in creation of the value of products, the size of which is determined by interrelation of demand and offer in the labor market. During the process of application to specific means of production, labor takes part in production of specific goods or services in the unity of all its manifestations.

A central multi-paradigm notion, characteristics of study of human capabilities for labor in the Russian science was traditionally "labor force". At that, most of the authors stick to K. Marx's treatment of this notion, as it most fully takes into account the moral and physical capabilities of individual and fully conforms to conditions of administrative \& command economy.

K. Marx's theory of science of labor consists in his implementation of peculiar treatment of the notion of "work force" which he described as, "Work force, or capability for work, is a totality of physical and moral qualities of the organism, of living person, and which are used by person every time he produces any consumer values" (Marx K., 1995). K. Marx stated that peculiarity of work force consists in the fact that it produces more than it's worth itself. Let us view this statement.

International bureau of labor treats work force as simply workers. "Work force is workers aged 16 and above, who already have a job or are in active search for it, or waiting that their services will be in demand after they're fired" - this is the treatment of this notion by modern American researchers (Rophe A.I., 2010).

The above definitions include various categories of population. These are employed and unemployed of certain 
age, including all employed and all unemployed, and those looking for hired work. Statistical data, under "Workforce in the region equals...", means the number of employed and unemployed, etc. It should be noted that if the same words mean different notions, the authors have to specify each time what they mean. Similar explanations are not always give, which leads to confusion in the usage of notions, related to, for example, "work force".

In the same way, work force can be understood as capability for work. In this case, we deal with labor potency of a human and with his capabilities. With this approach, work force is a physical phenomenon. In physics and mechanics, it is a value which is a measure of mechanical impact of one material body on another, which leads to changes in the state of a body - for example, its acceleration or deformation; force is characterized by certain numerical value, by action's direction in space and point of application.

If one considers work force as totality of moral and physical capabilities of a human which he spends during production of any consumer values, then the quality of work force will determine the result of future labor and its consumer value for employer.

Founding on such understanding of work force or worker's force, it is possible to name his capability to perform labor duties which, after its implementation, will quantitatively correspond to its possibilities. Of one works in full force, the result will be equal to its potency, and with the half-steam work, the result will be equal to half of the possibilities of human, etc.

In our opinion, in the labor market, buyer has a possibility to evaluate competitive characteristics of work force: physiological ones, level of education, professional knowledge, experience, competence, responsibilities, etc. However, during work life, these capabilities develop and renew; new capabilities are acquired, while unnecessary ones are lost. Thus, with the large scale of this notion, it is not sufficient for the analysis of labor processes and relation at the modern stage, as it fixes the presence of capabilities for labor, leaving aside the necessity for constant development of potential capabilities of human.

Thus, it should be repeated that K. Marx introduced the definition of the notion "work force" as human's capability for work (and not as human resource for work). Unlike physical sense of this notion, he formulated the provision stating that value of potency does not correspond to the received results, namely, that value of work force and value of its application - labor - are not the same (i.e., different). Value of work force, according to K. Marx's theory, is the value of assets, required for reproduction of employee and his family; the value of cost, created by labor, is greater than cost of work force, and he called this difference value added. In our opinion, the falsity of this provision is obvious - it comes up when viewing the issue, what is sold in the labor market. According to K. Marx, the labor market offered not labor but capability for labor - work force, which is exploited by employer (Marx K., 1995).

In modern economic theory, studies of categories of labor and workforce were continued.

$P$. Ignatovskiy supports the increase of attention to the role of labor factor and worthy evaluation of labor contribution to material production, stating that labor is a general source of material and moral goods (Ignatovskiy P., 1994).

E.I. Punin thinks that theory of marginal utility and labor theory of cost do not exclude but rather supplement each other (Punin E.I., 1993). He is supported by K. Howard, G. Zhuravleva, and N. Eriashvili which state in their work that if cost is labor input, than value reflects synthesis of input and results of this input (Howard K., 1997).

\section{Discussion and Results}

Together with category "work force, the Russian economic science also widely uses the category "labor resources" which was first introduced by academician S.G. Strumilin (Strumilin S.G., 1982). The opinions of scientists as to defining this category can be conventionally divided into three groups. The first group considers labor resources as a category of quantitative order, limited by age limits and depending on the form of production and level of development of production forces (Kulikov V.V., 2001). Variety of authors identifies labor resources with work force (A. Fayol, 1992). In our opinion, it is not right to equal these two categories, as labor resources are, primarily, people, category of country's population, while work force is creative capabilities of these people. That is, labor resources are carriers of functioning and potential (which does not participate in the process of labor) work force which possesses certain qualitative characteristics. Followers of the third direction, which we support, pay attention to socio-economic side of the category "labor resources" (Odegov Y.G., 1998). In economic literature, there is a predominating opinion of the authors which characterize labor resources as a part of country's population of working age, having the necessary physical and moral capabilities and employed in economy. A peculiarity of this opinion is that it vies potentially economically active part of population, not its qualitative characteristics.

Some authors (Shatalova N.I., 2003), in order to characterize human factor and human capability for labor, use the 
category of "labor potential". It characterizes not only used but unused - due to objective or subjective conditions possibilities which, if necessary, can enrich the process of production. That is, labor potential always contains certain reserve of unrealized possibilities which is caused not by coincidence of potential qualities of worker with current needs of production and conditions of their practical use. There is no single definition of this category, as well. Other authors identify "labor potential" with "labor resources", while others consider it to be a form of personal factor of production which in its development goes through several consequent stages; other authors determine labor potential as human capabilities for labor of certain complexity and qualification, on the basis of experience, received knowledge, and skills (Rozdolskaya I.V., 2013). In our opinion, substantial meaning of the term "labor potential" corresponds to characteristics of possibilities and capabilities of organization's staff which can be realized with emergence of needs for these capabilities, for change of character and content of labor, and more rational arrangement of workers in view of professional and qualification requirements.

Transformation of relations between worker and employer requires considering human as an active subject of the market and as an object of investments, required for his development. At present, the generalizing indicators of capabilities of creative activities of individual, of the level of development of human capabilities and mechanism for their formation is the notion of "human capital" used for characterizing the quality of workforce and worker's capabilities in the work process. The notion of "human capital" was first used by G. Becker in 1960s; he stated that investments into human created a certain regular source for feedback (income flow); at that, this feedback is significant and sustainable. According to G. Becker (Becker G., 1993), the size of human capital equals the volume of investments in education and, correspondingly, content of human capital - knowledge, received by worker, which can be accumulated.

Sharing this point of view, we consider human capital as production assets belonging to human (health, capabilities, knowledge, skills), allowing him to create income over a long period of time, and being the results of investments into them.

Thus, human capital is based on personality of specific worker, it is inseparable from human, and, consequently, its feedback will be determined by characteristics of personality (staff).

The notion of "human resources" was introduced in the works of some foreign scientists (Albert M., 1990, Friedmaiv S., 1994) and viewed as economic category, the definition of which comes from understanding that worker is the same production resource as land, materials, finances, etc. At that, this approach to determining the notion of "human resources" requires specifying due to the fact that it supposes "depersonalization" of workers.

In our opinion, the notion of "human resources" includes totality of characteristics and features of workers and in that sense reflects the main wealth of any country, region, sphere, and organization, the prosperity of which is possible with creating conditions for reproduction, development, and use of these resources in view of interests of each human. In our opinion, this understanding should be used at macro-economic level and for general study of resource flows of organization.

However, the most acceptable notion, reflecting individual and personified character of human as an object of management is, in our opinion, the notion of "staff".

Category of "staff", which denotes all employees (permanent and temporary), united as to professional or other attributes in separate groups, underlines the attitude towards people from the position of respect to their individuality and personality.

According to the concept of management of human resources, organization's staff is viewed as one of the types of tis resources which differs from other (financial, material, raw material) due to the fact that worker has a right to refuse from conditions of his usage, conduct negotiations as to the level of labor payment, train for other professions, take part in strikes, quit, and decide which professions are socially unacceptable (Fayol A., 1992). Subjectivity of this approach is marked by many researchers and is primarily caused by the fact that, on the whole, staff cannot be viewed as homogeneous substance, as each worker has individual peculiarities, motives, and values. In our opinion, this approach is based in the understanding people as object, not subject, of actions, i.e., it reflects manipulating, not mobilizing, view of people. In our opinion, the notions of staff as socio-economic category reflects the strive and form of realization of democratic initiatives for the formation of organization as a single social system, and it that sense it supposes certain integrity and social commonness of all workers of specific organization.

With all wideness of views on this category, most researchers agree that staff is the most complex object of management in organization, as, unlike, material factor of production, is possesses capability to independently decide, critically evaluate demands to it, act, and have subjective interests; it is very sensitive to managerial influence, the reaction to which is not determined (Martinova E.I., 2013).

Due to that, the most important practical task is creation of conditions which stipulate the fullest implementation of potential capabilities of human and his acquisition of new qualities and capabilities. It should be noted that with existing 
various approaches, the main criterion of referring certain individual to the "staff" group is its inclusion as a bearer of work force of certain quality into labor conditions within specific organization (Odegov Y.G., 1998).

The notion of "human resources" is introduced in works of variety of foreign scientists (Hollinshead G. Leat. M. Leopold J., Harris, 2000) and is viewed as an economic category, the definition of which comes from understanding that worker is the same production resource as land, materials, finances, etc. At that, this approach to determining the notion of "human resources" requires specification die to the fact that is supposes "depersonalization" of workers.

In our opinion, the notion "human resources" includes totality of characteristics and features of workers and in that sense reflects the main wealth of any state, region, sphere, and organization, the prosperity of which is possible with creation of condition for reproduction, development, and use of these resources in view of interests of each human. In our opinion, this understanding should be used at macro-economic level and for general study of resource flows of organization.

Very often, the notion "staff" is identified with the notion "human resources" - however, in our opinion, these terms include various meaning which is most clearly manifested under the conditions of modern economy.

Human resources are traditionally considered to be main part of qualified workers of enterprises and organizations who took preliminary professional training and who have work skills and work experience in certain sphere of activities. Thus, this category characterizes not a particular individual, but their totality which has certain professional level and are united into a group for the purpose of joint achievement of goals set for the organization. Unlike the staff, human resources include permanent personnel, the main task of which is provision of organization's functioning.

According to the definition by Administrative council of labor organization of 1978, the category of "professional workers" include the ones: having finished education or professional training or having acknowledged equivalent experience in scientific, technical, or administrative sphere; performs the functions of intellectual nature which require a high level of making conclusions and showing initiative, and supposing high level of responsibility (Hollinshead G. Leat. M. Leopold J., Harris, 2000 ).

In view of the above, we shall consider human resources as a core of organization's personnel, which is the most competent and prepared workers whose management and development allows providing "self-reproduction" of personnel even under the conditions of certain outflow of workers.

It is also necessary to dwell on the relations of categories "personnel" with the previously viewed notions of "work force" and "labor potential". As work force is a potential capability for labor, the role of traditionally important characteristic of personnel as an object of management belongs to labor potential of worker which was viewed as total capability of physical and moral features of particular worker to achieve - under set conditions - certain results of production activities, on the one hand, and capability for perfection during the process of labor and to solve new tasks, emerging as a result of changes in production, on the other hand (Shatalova N.I., 2003).

\section{Conclusion}

Labor market occupies one of the main roles in the system of market relations and is one of the most complex elements of market economy. The mechanism of the labor markets determines the level of wages and population's employment. In the labor market, a buyer has a possibility to evaluate competitive characteristics of work force: physiological (according to appearance and results of medical examination), education level (diploma), professional knowledge, experience, competence, responsibilities, etc. (according to the entries in work record book, current recommendations, and as a result of tests).

We think that labor market sells labor. Actually, when meeting in the labor market, worker and employer cannot sell or buy labor - as there is no labor yet: labor is functioning of a worker, its rational activities at production or in service sphere. However, the thing is that there could be no full comparison to the mechanism of functioning of labor market to the mechanism of functioning of product market: activities of labor market have its peculiarities, determined by specificity of the object of buy and sell.

While in the product market, the act of buy and sell take place momentarily, it begins and ends in the sphere of circulation, leading to buy and sell object's changing its owner, the labor market is not so simple. Agreement of buy and sell is done between subjects of labor market in the sphere of circulation, where employer and worker meet. However, realization of agreement's conditions can be done only after labor is performed.

In the labor market, worker and employer make an agreement on the future labor, on the labor which is to take place in the sphere of production, on payment for this labor, and other conditions, related to it. It is unlikely that employer would be interested only in capability for work without its realization. Employer is interested in the workers' labor as in one of the production factors, so he purchases the labor and pays for it. 
The authors wanted to receive the answer to the question, to what level of objectivity can labor cost be evaluated, using wages indicators as a measurer. Having analyzed the treatment of economic nature of wages by sources which belong to various economic schools, they complemented them and formulated the notion of wages in the market economy. This is the labor cost of work force of hired worker who created a part of product cost which corresponds to his ability for labor and ration of demand and offer of work force in the labor market.

We think that labor has its natural and market price. Natural labor price is the price, necessary for reproduction of work force which hired worker pretends to and which - with society's progress- has a tendency to increase. Market price of labor is the price paid for it due to natural ration of demand and offer. They formulate three variants of cost and price of work force:

1. If demand for work force is equal to its offer, wages (labor price) is equal to work force cost;

2. If demand for work force exceeds its offer, labor price in the form of wages is higher than work force cost;

3. In the situation when work force offer exceed the demand, labor price, i.e., offered wages, does not cover work force cost (Grigoryeva V.V., Polozova A.N. 2013).

Thus, review of multiple works of the Russian and foreign scientists, devoted to this problem, shows that analysis of the processes and relations in the sphere of labor includes various economic categories, like "work force", "labor resources", "labor potential", "human resources", "personnel", "human potential", and "human resources".

Market economy, based in the variety of forms of ownership and competition, creates stimuli for better labor. Work force, as capability for labor, is inseparable from human-worker, its bearer. It cannot become a property of work force buyer and if employer does not become an owner of work force, he cannot control it, as this right belongs only to the owner of work force. Sale of labor in the competitive labor market includes the equivalent exchange, where wages is the payment for labor use, i.e., payment for labor.

\section{References}

Albert M. HR Profit Power// Personnel, February. 1990.

Becker G. Economic analysis and human behavior // Thesis. - 1993. B. 1. No. 1 P. 24-40.

Grogoryeva V.V., Polozova A.N. Economic nature of competitive costs of production // Economy and entrepreneurship. 2013. No. (37). P. 431-435.

Ignatovskiy P. Labor and economy // Economist. 1994. No. 10. P. 69-82.

Friedmaiv S. Structure, Process and the Labor market// Labor Economics Modern Views. - Massachusetts. 1994.

Zhebelev S.A. Antique way of production in the sources. L. 1933. $554 \mathrm{p}$.

Hollinshead G. Leat. M. Leopold J., Harris. Strategic Human Resource. - Pearson Education, 2000.

Makrinova E.I. Terminological systematization of basic definitions of labor management in view of development of the theory of social and labor relations // Bulletin of Belgorod University of Cooperation, Economics, and Law. - 2013. - No. (48). - P. 120-127.

Marx K. Capital. Book 1. Process of capital production / K. Marx, F. Engels. 2nd ed. B. 23. 784 p.

Odegov Y.G. et al. Labor market and social partnership. - M.: Khronograf, 1998. - 315 p.

Petty W. Economic and statistical works /W. Petty. M. 1940. P. 8-55.

Punin E. I. Marketing, management and pricing at enterprise / E.I. Punin. M.: International relations. 1993. 196 p.

Ricardo D. B. 1-4, M.: Sotsekgis, 1958.

Rozdolskaya I.V., Ledovskaya M.E., Agaeva A.N. Status position of HR consulting under the growing processes of economic and informational integration and globalization // Bulletin of Belgorod University of Cooperation, Economics, and Law. 2013. No. 2 (46). P. $35-42$.

Roffe A.I. Labor economics: workbook / A.I. Roffe

Smith A. An Inquiry into the Nature and Causes of the Wealth of Nations / A. Smith. M. 1993. 452 p.

Modern labor economics: Monograph / Edited by V.V. Kulikov, Institute of Labor of the Ministry of Labor of Russia (Labor research institute). - M.: Finstatinform CJSC, 2001. $-660 \mathrm{p}$.

Strumilin S.G. Problems of labor economics. - M.: Nauka, 1982.

Management is science and art / A. Fayol, G. Emerson, F. Tailor, H. Ford. - M.: Respublika, 1992. - 351 p.

Howard K. Economic theory. Theory of free market. / K. Howard, G. Zhuravlyova, N. Eriashvili, M.: UNITI. 1997. 277 p.

Shatalova N.I. Labor potential of worker. - M.: 2003. -399 p. 